WIENER SLAVISTISCHES JAHRBUCH, Band 57/2011, 123-130

(C) 2011 by Österreichische Akademie der Wissenschaften, Wien

Mate Ka P OVIĆ

\title{
Shortening of the Slavic long circumflex - one mora law in Croatian
}

\section{INTRODUCTION $^{1}$}

The general reflexes of the Proto-Slavic old long circumflex $\left({ }^{*}\right)$ in Croatian have been known for a long time. In monosyllabic and disyllabic words (not counting the final yers) it yields Croatian long falling accent (c), cf. PS *gôrdъ > Croat. grâd 'town' and PS *zôlto > Croat. zlâto 'gold'. In contrast to this, the old *is shortened in trisyllabic and polysyllabic words, cf. PS * sŷnove $>$ Croat. sïnovi (: sîn < *sŷnъ) 'sons', PS *pôrsęte > Croat. präseta (: prâse < *pôrsę) 'pig'. This is uncontroversial and widely accepted ${ }^{2}$. However, this simplified approach does not really tell us what happens with the 'inbetween' cases, i.e. what happens with the words that have three syllables including the yers. In these cases, one finds examples which are not really clear at first glance, for instance the preservation of length in cases like glâdno < *gôldıno 'hungry' but shortening in cases like müško < *mỗžbsko 'male' (: mûž < *mộžb 'man'), or the preservation of length in cases like bûbanj < *bộbınъ 'drum' but shortening in cases like vjëčan < *věč̌nı 'eternal' (: vijêk< *vềkъ 'age'). It is obvious that some kind of explanation has to be given here since the quoted simple rule about disyllables and trisyllables does not help us here.

I have tackled this problem already in one of my articles (Kapović 2005a: 77-81) and I believe that the explanation given there is basically correct (cf. also Kapovic 2008: 13). However, some very important examples have not been discussed in that article and the case of the words like *mô̌žssko has not been properly explained there. Thus, a more detailed approach to the subject is needed as well as careful examination of additional data. That is the purpose of this article.

\footnotetext{
${ }^{1}$ I would like to thank Marko Kapović for proofreading the text.

2 See for instance Дыбо 2000: 18 for this kind of simple explanation.
} 
I have already tried to explain the shortening of pretonic length in Slavic with the help of morae. The claim is that pretonic lengths in Slavic are shortened in front of two or more morae (cf. Kapović 2005a: 101 and Holzer 2007: 74-75). There, the concept of morae is used to explain in which positions pretonic lengths are shortened and in which ones they are preserved. Mora is defined as follows: Slavic originally long vowels $\left({ }^{*} \mathrm{a}, *_{\mathrm{e}}, *_{\mathrm{i}},{ }^{*} \mathrm{u},{ }^{*} \mathrm{y},{ }^{*} \mathrm{e},{ }^{*} \mathrm{e}\right.$ and diphthongs $*^{*}$ or, ${ }^{*} \mathrm{er},{ }^{*} \mathrm{ol},{ }^{*} \mathrm{el}$, $\left.*_{\mathrm{br}}, *_{\mathrm{b}}, *_{\mathrm{b}}, *_{\mathrm{b}}\right)$ count like two morae ${ }^{3}$, Slavic originally short vowels $\left(*_{\mathrm{e}}, *_{\mathrm{o}}\right)$ count as one mora and the yers, the 'reduced' vowels $\left({ }_{\mathrm{b}},{ }^{*} \mathrm{~b}\right)$ count as half a mora. In this article, I shall try to prove that the shortening of the old long circumflex in Croatian can be explained via the morae concept as well.

\section{THE CONDITIONS OF THE SHORTENING OF THE LONG CIRCUMFLEX}

Here I shall adduce examples for the long circumflex shortening rule, which point to a variant treatment of the long circumflex in Croatian due to syllabic structure, i.e. to the number of morae after the long circumflex. The examples provided are those with a regular reflex. Words with analogical changes will be dealt with in the following text.
1) PS *mŷ > Northern Čakavian/Kajkavian $m \hat{\imath}$ we
2) PS *dârb $>$ Croat. dâr gift
3) *zôlto > zlâto gold
c) *bộbınъ > bûbanj drum
d) *môिžbsko > müško male
e) *môldostь > mlädōst youth
f) *sŷnove > sïnovi sons

The example of $m \hat{\imath}$ shows the preservation of the long circumflex in monosyllabic words ${ }^{4}$. Additional examples from the same dialects are $t \hat{\imath}$ thou, $v \hat{\imath}$ you. As for Štokavian, one could cite aorist 2 nd and 3rd person sg. like $p \hat{\imath}<*$ pî 'drank' (from pïti 'drink') for the same kind of development. However, these kinds of examples are not really reliable since it is quite certain that their actual Proto-Slavic form was *pît ${ }^{5}$ and that the ending *-tъ was subsequently lost in Croatian (like in the 3rd sg. of the present tense).

${ }^{3}$ Except in the final open syllable where they are shortened (like in *rōkä > *oōkà) and thus count as a short vowel. In traditional accentological approach, all lengths in final open syllables are shortened. However, if one accepts that some lengths are preserved in final open syllables (like Croat. dial. instr. sg. $-\tilde{\imath}<*-\tilde{y}$ in $o$-stems), then, of course, those are counted as two morae as well and pretonic length is shortened in front of them.

4 Standard Croatian (i.e. Neo-Štokavian) $m \hat{\imath}$ derives from the older form $m \tilde{\imath}$, which has a secondary accent by analogy to jã (cf. Kapović 2006: 55).

5 One would expect this secondary ending exactly in a. p. $c$, where the circumflex appears (cf. Дыбо 2000: 304-309). 
Examples like dâr and zlâto are not problematic. The long circumflex is always preserved in such examples. The short falling accent in cases like the prefixed 2nd/3rd person aorist like näp $\overline{\bar{l}}$ (from nàpiti 'get drunk') is either regular from the form *nâpiţ (which would behave like *môldostı) or is analogical to pöp pòpiti 'drink up') that has an original short vowel ${ }^{6}$.

Like dâr and zlâto, the reflexes mlädōst and sïnovi are also not very problematic and here I refer to Kapović 2005a: 80-81. However, a few things need to be discussed. Basically, there is no difference between shortening in mlädōst and shortening in müško. In both cases, the long circumflex is shortened in front of one and a half mora (one full vowel + one yer), the difference being only in their sequence. Thus, it seems logical to assume that the long circumflex was treated in the same way in both cases. The shortening like mlädōst also explains why prepositions, conjunctions and particles that obtain the absolute initial falling accent in the enclinomena forms of the mobile accentual paradigm (a. p. c) ${ }^{7}$ like nä glāvu $<{ }^{*}$ nâ golvQ 'on the head' almost always have ". Forms like $n \ddot{l} b \bar{o} g<*$ nî bogъ behave like *môldostı and forms like nä oko < *nâ oko 'on the eye' behave like *sŷnove. However, there is one exception - dialectal forms like zâ me <*zâ mę 'for me', nâ te < *nâ tę 'on you' etc. ${ }^{8}$ Here, the long falling accent is preserved like in the example zlâto.

There are some examples in which there seems to be no shortening of the sïnovi type. A case in point would be possessive adjectives ending in -ov like vûkov, vûkovo ' 'wolf's' or mûžev, mûževo 'husband's', where one would expect shortening. However, these are easily explained by analogy to the basic nouns vîk, mûž. Cf. the original shortened forms in dial. forms kümovu (fem. acc. sg.), kümovi (masc. nom. pl.) from kûm - kûma 'best man' in Donja Bebrina in Posavina (Old Štokavian) ${ }^{10}$. In the standard language, the accent is levelled - kûmov, kûmovi by analogy to kûm. See also a place name Vükovo Selö in the Lower Sutla (donjosutlanski) Kajkavian/ Cakavian dialect ${ }^{11}$ and compare it with the usual possessive adjective vûkovo. Secondary analogical length of the same type is also seen in the name Tijelovo 'Corpus Christi', where the orthography $\langle$ Tijelovo $\rangle$ itself points to the length. This is analogical to the basic form tijelo 'body' and the original shortened form can be seen in the alternative form Tjëlovo, which is also a very common pronunciation.

${ }^{6}$ The former is a possibility in the case one would refrain from reconstructing the ending $*_{\text {-tъ }}$ in these aorist forms.

${ }^{7}$ Forms $a, b, c$ are used for Proto-Slavic accentual paradigms and A, B, C for modern (Croatian) accentual paradigms. A colon (:) is used to indicate the length of modern accentual paradigms (B:, C:).

8 Cf. Kapović 2006: 43, 80-81.

9 The feminine form vûkova is analogical, in Proto-Slavic it was *vukovà, cf. Дыбо 1981: 126.

10 My data.

11 DGO 2007: 220. 
There are more problems concerning examples like *bộbınъ > bûbanj and *mô̄žbsko > müško. Here we propose that the old long circumflex is regularly maintained in words like bûbanj (i.e. words having two yers after the circumflex) and that it is shortened in all other cases - that is, in all cases that have one full vowel plus a yer, two full vowels etc. So the limit of the preservation of length is at two yers after the accent, i.e. one mora. Since every yer counts as half a mora, two yers count as just one mora, so examples like *bôbınъ are in mora terms the same as examples like *zôlto and that is why the length of the circumflex is preserved there. That is also why we posit the one mora law that says: Proto-Slavic long circumflex is preserved in Croatian only in front of one or fewer morae ${ }^{12}$.

There are a couple of problems with examples like *bôbbnъ > bûbanj. First of all, one would expect shortening in the oblique forms of the word. Forms like *bọbsna (gen. sg.) and *bôbbnu (dat. sg.) should yield *bübnja, *bübnju, in the same way as *mô̌žbsko yields müško. It is obvious that the attested forms bûbnja, bûbnju are analogical to the nom/acc. sg. bûbanj. This kind of levelling is clearly attested in the word lakat 'elbow'. Here, in place of Proto-Slavic *ôlkstı we find in Croatian two variants: läkat and lakkat, both widely attested in various dialects. How did this situation come about? What we expect from the old *ôlkъtb, gen. sg. *ôlksti is Croatian *lâkat, gen. sg. *läkta (with a transfer to $o$-stems). This alternation was then resolved by various dialects generalizing one form or the other ${ }^{13}$. Another clear case of shortening of the müško type is the acc. sg. djëcu <*dễtbce 'children' (cf. dijéte 'child'). The nom. sg. form djèca has the short syllable by analogy to the forms with the initial accent. As for the form sïce 'heart', I shall not discuss this problematic form here again. There are many indices that point to the Proto-Slavic form *s sirdsce and thus to the shortening of the old long circumflex, but this kind of form is problematic in Proto-Slavic (one would expect *sbrdbce). For more cf. Kapović 2005a: 80f and Kapović 2005b.

The main chunk of evidence for different results of levellings in the läkat/lâkat type words comes from ${ }^{*}$-ьnъ and ${ }^{*}$ - Łkъ adjectives. Here, in accentual paradigm $c$ one can reconstruct Proto-Slavic forms like: *gôlsınъ - *golsınà - *gôlssno 'loud'

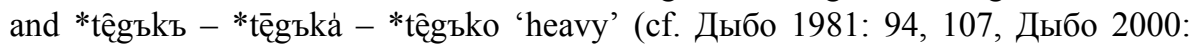
$159,171)$. Up until now, it has been mostly taken for granted that length is preserved in forms like Croat. glâsan - glásna - glâsno and têžak - téška - têško. However, according to the one mora law we posited, one would not expect a complete maintenance of length but a complicated set of short/long alternations in various forms of these adjectives.

12 Actually, by analogy to the two morae law (pretonic length is shortened in front of two or more morae), one would expect the name one and a half morae law, but this name was not chosen for obvious reasons.

13 Cf. also the case in Dubrovnik, where lakat is 'elbow' and läkat is 'ell' (ARj). 
In Proto-Slavic, we find ${ }^{14}$ :

masc. - neut. - fem.

N. *gôlsьnъ - *gôlsьno - *golsnà

G. *gôlsьna - *golsьný

D. *gôlssnu - (*gôlsьně $)$

A. *gôlsьnъ - *gôlsьno - *gôlsьne

L. *gôlsьně - (*golsьnĕ $)$

I. (*gôlsbnomь) - *golsьnojQ̀

n. *gôlsьni - *golsınà - *gôlsıny

(g. *golsьnь)

(d. *golsьnomb - *golsьnämъ)

a. *gôlssny - *golsıná - *gôlssny

(1. *golsьněxъ่ - *golsьna̋xъ)

(i. *golssný - *golsınämi)

In Croatian, one would expect the following paradigm after the phonetic shortening of the one mora law:

masc. - neut. - fem.

N. *glâsan $-{ }^{*}$ gläsno $-{ }^{*}$ glāsnä ${ }^{15}$

G. *gläsna - *glasnẽ

D. *gläsnu

A. *glâsan/gläsna - *gläsno - *gläsnu

L. *gläsně (*gläsnu)

I. *glasnõm

n. *gläsni - *glāsnä - *gläsne

a. *gläsne - *glāsnä - *gläsne

The same type of pattern would be expected in *têžak - *tëško - *teškä etc. This kind of length alternation was hardly maintainable, so what occurred was that either short or long forms were generalized. In some cases, only the long form is attested (like in glâdan < *gôldbnъ 'hungry'), in others it is just the short form that is attested (like in vjëčan < *věčsnъ or krëpak < *krềpъkъ 'brisk') and in some cases both

\footnotetext{
14 The forms in brackets are the ones that have not been reflected in Croatian. Instead of them, definite endings were taken.

15 For the preservation of length here, cf. plátno < *poltınó (Kapović 2005a: 89-90).
} 
forms are present (like in gläsan/glâsan $<*$ gôlsınъ or tëžak/têžak $<*$ tę̣gъkъ) ${ }^{16}$. Generalizing the length meant maintenance of the a. p. C mobile accent, while generalizing the shortened forms meant a shift to a. p. A (gläsan-gläsna-gläsno).

Here is the exact situation in ${ }^{*}$-ьnь adjectives ${ }^{17}$ :

a) only short stem attested

rëdan orderly, slästan delicious, spräsna with young (of sows), ždrëban with young (of mares) ${ }^{18}$

b) short stem in some dialects, long in others

bïtan/bîtan important, gläsan/glâsan loud, gnjüsan/gnjûsan dispicable, krëpan/ krijêpan brisk, mästan/mâstan greasy (A in Kajk.) ${ }^{19}$, mïran/mîran still (A in Kajk.), präšan/prâšan dusty, sjäjan/sjâjan glowy (A in Kajk.), skr̈ban/skr̂aan caring (A in Kajk.), snjëžan/snijêžan snowy, srâman/sräman ashamed (A in Kajk.), sträšan/strâšan terrifying, svjëstan/svijêstan aware, vjëčan (Vuk vïječan), zräčan/zrâčan airy (A in Kajk.), žüčan/žǔčan bitter $^{20}$

c) only long stem attested

bijêsan furious, bûdan awake, glâdan, hlâdan cold, mrâčan dark, zlâtan golden ${ }^{21}$

In the *-๖kъ adjectives, the end results are slightly different, looking at the numbers of various types of levellings (but there are far fewer examples here than in *-ьnъ adjectives):

a) only short stem attested

brïdak sharp, d̈̈zak daring, krëpak, kr̈hak fragile, slädak sweet

${ }^{16}$ In some dialects, combined forms are attested, cf. in Sikerevci (Posavina, Old Štokavian -

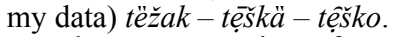

17 For the reconstruction of Proto-Slavic accentual paradigms, cf. Дыбо 1981: 72-107, Дыбо 2000: 154-175. Also, some of the information relevant for the reconstruction of particular accentual types is provided briefly in the footnotes.

18 Cf. rêd - rêda order, slâst - slâsti relish (also *sôldъkъ 'sweet'), prâse - präseta pig (also Siče in Posavina 3rd sg. se prasĩ farrows), ždrijêbe - ždrëbeta foal (also Siče in Posavina 3rd sg. se ždrebĩ foals).

${ }^{19}$ In Kajkavian, generalization of the short variant occurs in cases in which it nevers occurs in Štokavian or Čakavian.

${ }^{20}$ Cf. bît - bîti essence (also bïti - bila be - was), glâs - glâsa voice, gnjûs - gnjûsa scoundrel, Slovene krepim (also *krěpŁkъ 'brisk'), mâst - mâsti fat (also Siče in Posavina 3rd sg. mastĩ), Kajkavian/Čakavian mîr - mîra peace (Štokavian míra is secondary), prâh - prâha dust (also Siče 1st sg. prašĩm), sjâj - sjâja glow, skr̂b - skr̂bi care, snijêg snijêga snow, srâm - srâma shame, strâh - strâha fear (but sträšiti scare), svijêst svijêsti counsciousness, zrâk - zrâka air, žûč - žûči bile.

${ }^{21}$ Cf. bijês - bijêsa rage, Siče in Posavina 3rd sg. budĩ awakens, glâd - glâdi hunger, hlâdhlâda shade, mrâk - mrâka dark, zlâto gold. 
b) short stem in some dialects, long in others mëk(ak)/mêk soft, pütak/pîtak drinkable, tëžak/têžak, vïtak/vîtak $\mathrm{slim}^{22}$

Various kinds of levellings of shortness/length and various types of double forms in *-ьnъ and *-ъkъ adjectives cannot be explained in any other way than by assuming the existence of the one mora law ${ }^{23}$. Thus these types of adjectives provide valuable additional data for the discussion of the rules for the shortening of the ProtoSlavic long circumflex in Croatian.

\section{Literature}

ARj:

DGO 2007:

Дыбо 1981:

Rječnik hrvatskoga ili srpskoga jezika. Vol. 1-97 [parts I-XXIII], Zagreb 1881-1976

Дыбо 2000:

Božica Jakolić - Jasna Horyat, (ed.), Donjosutlanski govor i običaji. Zbornik kajkavske ikavice, Šenkovec

Holzer 2007:

Владимир А. Дыбо, Славянская акцентология. Опыт реконструкции системы акцентных парадигм в праславянском, Москва

Владимир А. Дыбо, Морфологизированные парадигматические акцентные системы. Типология и генезис, Том I, Москва

Holzer 2007: Georg Holzer, Historische Grammatik des Kroatischen. Einleitung und Lautgeschichte der Standardsprache, Frankfurt am Main - Berlin - Bern - Bruxelles - New York - Oxford - Wien

Kapović 2005a: $\quad$ Mate Kapović, The Development of Proto-Slavic Quantity (from Proto-Slavic to Modern Slavic Languages), Wiener Slavistisches Jahrbuch 51, 73-111

Kapović 2005b: $\quad$ Mate Kapović, Naglasak praslavenske riječi *sbrdbce, Croatica \& Slavica Iadertina I, 125-133

Kapović 2006:

Mate Kapović, Reconstruction of Balto-Slavic Personal Pronouns with Emphasis on Accentuation, University of Zadar [unpublished $\mathrm{PhD}$ dissertation]

Kapović 2008:

Kapović forthc.:

Mate Kapović, Razvoj hrvatske akcentuacije, Filologija 51, 1-39

Mate Kapović, Historical Development of the Adjective Accentuation in Croatian (Suffixless, *-ьnъ and *-ъkъ adjectives), Baltistica (Proceedings from International Workshop on Balto-Slavic Accentology 6) (forthcoming)

${ }^{22}$ Cf. pïti - píla - pöpīt 'drink - drank - drunk' and vïti - víla - zävīt 'flutter/wind folded'. The rest of the *-ъkь adjectives are reconstructed as a. p. $c$ by Дыбо.

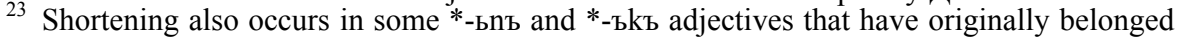
to a. p. b, cf. for instance grëšan 'sinful' and krätak 'short'. However, this process is not directly connected to the shortenings in the a. p. $c$ and does not undermine our analysis presented here. More on this in Kapović forthc. 
A b stra ct: Shortening of the Slavic long circumflex - one mora law in Croatian. The article deals with the precise rules for the shortening of the Proto-Slavic old long circumflex in Croatian. The conditions of the shortening are explained in mora terms and a special emphasis is put on the evidence coming from -an and -ak adjectives.

K e y w or d s : Croatian, Proto-Slavic, Slavic, accentuation, shortening, circumflex

\author{
Mate Kapović \\ Department of Linguistics \\ Faculty of Humanities and Social Sciences \\ University of Zagreb \\ Ivana Lučića 3 \\ 10000 Zagreb, Croatia \\ mkapovic@ffzg.hr
}

